\title{
Pengaruh Faktor-Faktor Produksi Terhadap Produktivitas Usaha Tani Padi Sawah di Kelurahan Ngkari-Ngkari Kecamatan Bungi Kota Baubau
}

\author{
1Wa Ode Al Zarliani
}

Email: wd.alzarliani@gmail.com

\begin{abstract}
Abstrak
Tujuan penelitian ini (1) untuk mengetahui pengaruh luas lahan, bibit, tenaga kerja, pupuk, dan pestisida secara simultan terhadap produktivitas usaha tani padi sawah; dan (2) untuk mengetahui pengaruh luas lahan, bibit, tenaga kerja, pupuk, pestisida dan terhadap produktivitas usaha tani padi sawah. Populasi dalam penelitian ini adalah keseluruhan petani yang mengusahakan tanaman padi sawah yang berjumlah 470 orang. Penentuan sampel dilakukan dengan metode simple random sampling dengan mengambil 10\% dari populasi, sehingga diperoleh jumlah sampel 47 responden. Selanjutnya data ditabulasi dan dianalisis dengan teknik analisis regresi linear berganda. Hasil penelitian diperoleh bahwa terdapat pengaruh Faktor-faktor produksi secara simultan terhadap produktifitas pada usahatani padi sawah dengan pengaruh sebesar 75,9\% dan selebihnya 24,1\%\% dipengaruhi oleh faktor lain. Nilai signifikansi lahan $(X 1)=0,009$, bibit $(X 2)=0,040$, Jumlah tenaga kerja $(X 3)=0,981$, Pupuk $(X 4)=0,013$, pestisida $X 5=0.000$. dari hasil tersebut, tenaga kerja tidak berpengaruh signifikan sedangkan luas lahan, bibit,pupuk dan pestisida berpengaruh signifikan terhadap produktivitas usaha tani padi sawah dengan persamaan Regresi $Y=1370,989-802,119$ X1 + $11,107 X 2-101 X 3+1.010 X 4+519,958 X 5+e$.
\end{abstract}

Keywords: Usaha Tani; Sawah; Padi

\begin{abstract}
The objective of this research was to know the effect of extensive area, seed, labour, fertilizer, pesticide simultaneously to the productivity of rice plant farming trade. The population in this research was all the farmers who plant rice. They were 470 persons. The determination of samples was done by using random sampling method. It was taken 10\% from the population, so the total respondens were 47 persons. Then the data was tabulated and analysed by the technique of bifilar linear regretion analysis. The result of this research stated that there was effect of production factors simultaneously to the productivity rice plant farming trade with the mean score was $75,9 \%$ and $24,1 \%$ affected by another factors. The value of significant area was $(X 1)=0,009$, seed $(X 2)=0,040$. The total number of labours was $(X 3)=0,981$, fertilizer was $(X 4)=0,013$, pesticide was $X 5=0.000$. From those results, it could be revealed that labour didn't have significant effect, whereas the extensive area, seed, fertilizer, and pesticide had significant effect to the productivity of rice plant farming trade with the regretion similarity was $Y=1370,989-802,119$ X1 + 11,107 X2 -101 X3 + 1.010 X4 + 519,958 X5 +e.
\end{abstract}

\footnotetext{
${ }^{1}$ Fakultas Pertanian, Universitas Muhammadiyah Buton, Indonesia
} 


\section{INTRODUCTION}

Pembangunan sektor pertanian merupakan hal yang sangat penting dalam pembangunan Indonesia. Hal ini karena lebih dari 55\% penduduk Indonesia bekerja dan melakukan kegiatannya di sektor pertanian dan tinggal di perdesaan. Berkaitan dengan hal tersebut maka kebijakan yang ditempuh dalam pelaksanaan Pembangunan sektor Pertanian lebih menekankan pada aspek pemberdayaan, baik pemberdayaan sumberdaya manusia, pemberdayaan sumberdaya alam maupun aspek manajemennya. Pembangunan di Indonesia mengalami guncangan dengan adanya krisis ekonomi. Walaupun begitu dampak dari krisis ekonomi di sektor pertanian ini pun tidak begitu terasa dari pada di sektor industri. Oleh karena itu kebijakan yang memanfaatkan kekuatan sendiri tidaklah salah apabila salah satunya dicapai melalui usaha peningkatan sumber daya di sektor pertanian.

Dalam (Biro Pusat Statistik, 1993), dapat dilihat bahwa dari tingkat pendidikan dan tingkat usia, ternyata mutu SDM di sektor pertanian relatif rendah, disamping tingkat pendidikan yang rendah, tingkat usia rata-rata petani pun makin tua dan ini sangat berpengaruh terhadap produktivitas sektor pertanian. Di samping itu, nampak bahwa pertanian di Indonesia didominasi oleh petani yang tergolong peasant atau subsistence farmers yaitu petani yang mempunyai lahan sempit (kurang dari 0,5 Ha) dan memanfaatkan sebagian besar dari hasil produksinya untuk kebutuhan sendiri. Menurut (Sufridson, 1989) terdapat dua kelompok utama yang menjadi hambatan di dalam pengembangan usaha tani, yaitu (1) faktor-faktor yang termasuk dalam kelompok ekonomi dan (2) faktor-faktor yang termasuk dalam kelompok biologi. Kelompok penghambat pertama dan kedua saling berkaitan dan saling pengaruh memengaruhi namun dapat dipisahkan secara tegas.

Menurut (Soekartawi, 1990) pemisahan kedua faktor tersebut dapat dijelaskan secara tegas, yaitu (1) Faktor biologi, seperti lahan pertanian dengan macam dan tingkat kesuburannya, bibit, varitas, pupuk, obat-obatan, gulma dan lain sebagainya dan (2) Faktor sosial ekonomi, seperti biaya produksi, harga, tenaga kerja, pendidikan petani, tingkat pendapatan, risiko dan ketidakpastian, kelembagaan, tersedianya kredit, dan sebagainya. Disamping itu, permasalahan yang dihadapi sektor pertanian secara umum pada era industrialisasi nanti adalah adanya kenyataan terjadinya perpindahan tenaga kerja dari sektor pertanian ke sektor non pertanian. Hal ini disebabkan pertumbuhan industri yang lebih cepat membutuhkan tenaga kerja yang semakin banyak, sehingga tenaga kerja di sektor pertanian menjadi langka. Dengan adanya perbedaan-perbedaan lingkungan fisik, sosial dan ekonomi maka petani menghadapi masalah alokasi sumber daya yang dimiliki. Sebenarnya peranan petani adalah bagaimana mengambil keputusan pada pemilihan sumberdaya yang ada dalam mengelola lahan Usaha taninya agar dapat memberikan manfaat yang sebesarbesarnya, sehingga akan berpengaruh terhadap pendapatan maupun efisiensi Usaha taninya.

Sektor tanaman pangan khususnya padi sawah merupakan salah satu subsektor pertanian yang memiki peranan strategis bangsa Indonesia karena beras merupakan makanan pokok bagi sebagian besar rakyat Indonesia serta merupakan sumber pendapatan bagi para petani di perdesaan. Usaha tani padi sawah memiliki peranan multi fungsi yang besar dan keberhasilan pengembangannya akan memberikan pengaruh yang nyata terhadap pencapaian ketahanan pangan dan kesejahteraan petani. Selama ini pengembangan produksi padi dilakukan 
melalui peningkatan produksi, perluasan areal juga petani didorong untuk meningkatkan produktivitasnya yang pelaksanaanya perlu dilaksanakan secara terencana dan berkelanjutan melalui peningkatan mutu intensifikasi dengan menerapkan paket teknologi budidaya tanaman padi sawah melalui program - program penyuluhan pertanian

Untuk meningkatkan produktivitas padi sawah selain dipengaruhi oleh sumberdaya alam, juga dipengaruhi oleh faktor produksi lainnya serta penerapan teknologi yang memadai, dan penggunaan tenaga kerja (Soekartawi, 1990) Kota Baubau merupakan salah satu penghasil padi sawah yang ada di Propinsi Sulawesi Tenggara. Lokasi penanaman padi sawah terkosentrasi pada 3 Kecamatan yakni Kecamatan Sorawolio dengan luas panen sebesar 103 Hektar serta hasil produksi sebesar 391,40 ton, Kecamatan Bungi dengan luas panen 2.138 Hektar serta hasil produksi sebesar 9.621 ton, dan Kecamatan Lea-lea dengan luas panen 103 Hektar serta hasil produksi sebesar 640 ton. Bila dibandingkan dengan tahun 2011 maka produksi padi sawah pada tahun 2012 terjadi penurunan sebesar 12.79 ton (BPS, 2013)

Data Perkembangan Luas panen, Produksi dan Produktivitas Padi Sawah Kota Baubau Tahun 2010- 2012. Perhatikan tabel berikut.

Tabel 1. Luas panen, Produksi dan Produktivitas Padi Sawah Kota Baubau Tahun 2010- 2012

\begin{tabular}{cccc}
\hline Tahun & $\begin{array}{c}\text { Luas } \\
\text { panen } \\
\text { (Ha) }\end{array}$ & $\begin{array}{c}\text { Produksi } \\
\text { (Ton) }\end{array}$ & $\begin{array}{c}\text { Produktifitas } \\
\text { (Kw/Ha) }\end{array}$ \\
\hline 2012 & 2.344 & $10.652,40$ & 45,45 \\
2011 & 2.460 & $12.214,68$ & 49,65 \\
2010 & 2.516 & 12.364 .70 & 39,00 \\
\hline
\end{tabular}

Submber: Data BPS Kota Baubau

Ketika luas panen terus menurun, rata-rata produksi padi mengalami fluktuasi, penyebab fluktuasi ini adalah karena penggunaan faktor produksi luas lahan tidak tepat. Faktor lahan merupakan faktor produksi yang paling besar pengaruhnya dalam menentukan tingkat produksi padi. Produksi juga sangat dipengaruhi oleh penggunaan faktor produksi bibit dan pupuk terhadap jumlah produksi padi. Pemupukan yang teratur dan disesuaikan dengan kebutuhannya maka hasil produksi Usaha tani akan lebih maksimal, karena dengan pemanfaatan fungsi lahan serta didukung pemupukan yang baik serta penggunaan bibit unggul maka terciptalah hasil produksi yang bermutu.

Kecamatan Bungi, dilihat dari aspek ekologis, Kota Baubau merupakan daerah yang potensial untuk pengembangan usaha tani padi, hal ini dapat dicermati dari luas panen tanaman padi sebesar 2.138 Hektar. (BPS Kota Baubau, 2013). Produktivitas padi di Kota Baubau masih tergolong rendah. Pada tahun 2012 BPS melaporkan bahwa luas panen padi di Kota Bau 2.344 ha dengan produksi $10.652,40$ ton, sehingga produktivitasnya hanya 4,54 Ton/Ha. Produktivitas ini masih di bawah produktivitas nasional yang mencapai 4,999 Ton/Ha (BPS, 2011). Besar kecilnya produktivitas padi sawah tergantung pada faktor-faktor produksi yang digunakan, antara lain benih, pupuk, pestisida, irigasi dan tenaga kerja. Berdasarkan uraian di atas, maka fokus penelitian ini adalah bagaimana pengaruh faktor-faktor produksi terhadap produktivitas usaha tani padi sawah di Kelurahan Ngkari-Ngkari Kecamatan Bungi, Kota Baubau?

Tujuan penelitian ini untuk mengetahui pengaruh faktor-faktor produksi terhadap produktivitas usaha tani padi sawah di Kelurahan NgkariNgkari Kecamatan Bungi, Kota Baubau.

\section{METODE PENELITIAN}

\subsection{Populasi dan Sampel Penelitian}

Menurut

(Arikunto, 2002) menyatakan bahwa, "Populasi adalah keseluruhan obyek penelitian yang digunakan sebagai sumber data". 
Berdasarkan pendapat tersebut di atas maka dapat disimpulkan bahwa populasi adalah keseluruhan obyek penelitian yang mempunyai karakteristik tertentu dan digunakan sebagai sumber data dalam suatu penelitian. Dalam penelitian ini yang dijadikan populasi adalah petani yang melakukan kegiatan usaha tani padi sawah pada musim tanam. Jumlah populasi dalam penelitian ini sebanyak 470 petani. Mengingat cukup banyaknya populasi petani yang akan diteliti maka peneliti hanya akan mengambil sebagian dari populasi yang ada dengan mengumpulkan sampel. Berdasarkan penjelasan di atas peneliti mengambil sampel sebanyak $10 \%$ dari 470 petani yaitu sebanyak 47 petani responden Penentuan sampel dilakukan dengan cara acak sederhana (Simple Random Samping) sebanyak 47 orang dari jumlah populasi. Sampel yang dipilih sudah mewakili dari keseluruhan populasi yang ada.

\subsection{Jenis dan Sumber Data}

Data terbagi 2, yaitu data primer dan data sekunder. Data primer yaitu data yang diperoleh secara langsung dari sumber-sumber terpercaya di lokasi penelitian, yakni dengan melakukan observasi langsung ke obyek yang diteliti melalui wawancara (interview) kepada para responden/informan dengan menggunakan kuisioner yang telah disiapkan sebelumnya. Hal ini dimaksudkan untuk memperoleh data atau keterangan yang jelas sehubungan dengan obyek penelitian ini. Sedangkan data sekunder yaitu data yang diperoleh dari berbagai sumber, seperti literatur dan atau buku-buku perpustakaan, arsiparsip/data-data yang ada pada obyek penelitian (kantor Kecamatan Bungi dan Biro Pusat Statistik Kota Baubau.) serta referensi-referensi lainnya yang relevan dengan obyek yang diteliti atau dikaji. Sumber data meliputi : orang, literatur, dokumen dan suasana (observasi).

\subsection{Variabel Penelitian}

Variabel dalam penelitian ini, yaitu (1) Faktor-faktor produksi meliputi luas lahan, pupuk, bibit, pestisida, jumlah tenaga kerja; Produksi pada usaha tani padi sawah (kg); dan (3) Produktivitas padi sawah $(\mathrm{Kg} / \mathrm{Ha})$.

Teknis analisis data yang digunakan dalam penelitian ini adalah Analisis Regresi linear berganda dengan persamaan sebagai berikut:

$Y=a+b_{1} x_{1}+b_{2} x_{2}+b_{3} x_{3}+b_{4} x_{4}+b_{5} x_{5+\mathrm{e}}$

Keterangan

$\mathrm{Y}=$ Produktifitas padi sawah $(\mathrm{Kw} / \mathrm{Ha})$

$\mathrm{X}_{1}=$ Luas lahan garapan $(\mathrm{Ha})$.

$\mathrm{X}_{2}=$ Bibit

$\mathrm{X} 3=$ Tenaga kerja

$X_{4}=$ Pupuk

$X 5$ = Pestisida

\section{Uji F}

Uji statistik $F$ pada dasarnya menunjukan apakah semua variabel bebas yang dimasukan dalam model mempunyai pengaruh secara bersamasama terhadap variabel terikat. Artinya apakah semua variabel penjelas secara bersamaan merupakan variabel-variabel penjelas yang signifikan atau tidak signifikan terhadap variabel dependennya. Secara statistik formulasi uji $\mathrm{F}$ adalah (Gujarati, 2003):

$F=\frac{R^{2} /(k-1)}{\left.1-R^{2}\right)(n-k)}$

Bila $\mathrm{F}$ hitung $>\mathrm{F}$ tabel pada lingkal derajat kepercayaan $5 \%$ dan tingkat kepercayaan terteniu atau nilai probabiliias signifikansi lebih kecil dari 0,05 maka HO dilolak yang berarti variabel bebas secara bersama-sama memengaruhi variabel terikat

Ujit

Uji statistik $t$ pada dasarnya adalah menunjukkan seberapa besar pengaruh satu variabel penjelas secara individual dalam memengaruhi variabel terikat. Apakah suatu variabel indipenden merupakan penjelas yang signifikan atau 
tidak signifikan terhadap variabel dependen. Dalam statistik dapat dicari melalui rumus (Gujarati, 2003):

$\mathrm{t}$ $\beta i$

\section{Se $(\beta \mathrm{i})$}

dimana $\mathrm{t}=$ nilai yang dicari; $\mathrm{pi}=$ koefisien regresi dan se $=$ standar eror koefisien regresi. Bila $\mathrm{t}$ hitung $>$ Tabel pada tingkat kepercayaan $5 \%$ atau nilai probabilitas signifikansi lebih kecil dari 0,05 (taraf nyata 5\%) maka HO ditolak dengan kata lain variabel bebas berpengaruh secara signifikan terhadap variabel terika. Selanjutnya penyelesaian analisis ini menggunakan program SPSS Versi 19.00, sehingga unluk menilai hasil regresi dilakukan dengan melihai nilai masing-masing koefisien dari keluaran program SPSS tersebut.

\section{HASIL DAN PEMBAHASAN}

\subsection{Identitas Petani Sampel}

Identitas petani responden yang dimaksud dalam penelitian ini adalah identitas petani yang merupakan penunjang keberhasilan dalam melakukan kegiatan usaha tani padi sawah. Identitas petani responden yang diuraikan dalam hasil penelitian ini meliputi umur, pengalaman berusaha tani, tingkat pendiddikan, jumlah tanggungan keluarga, luas lahan garapan.

\section{a. Umur}

Umur merupakan salah satu faktor yang memengaruhi kemampuan petani untuk melakukan kegiatan usaha tani dan kesiapan petani untuk menerima hal - hal baru. Umur pada usia produktif merupakan masa terbaik bagi petani untuk menerima suatu hal-hal baru terutama dalam penerapan teknologi. Karena pada umur muda tersebut umumnya petani mempunyai partisipasi yang maksimal untuk melakukan kegiatan usaha taninya. Hal ini didukung oleh (Soeharjo \& Patong, 1984) bahwa petani muda lebih dinamis sehingga lebih cepat menerima hal-hal baru yang dianjurkan. Hal ini disebabkan karena petani yang berusia muda lebih dinamis dan lebih berani menanggung risiko sehingga lebih cepat mendapatkan pengalaman-pengalaman baru yang berharga bagi perkembangan kegiatan usahataninya pada masa yang akan datang.

Umur dapat memengaruhi kemampuan fisik seseorang, baik dalam cara berpikir untuk memecahkan setiap persolan yang ada maupun dalam bekerja. Umur muda mempunyai kemampuan yang lebih tinggi bila dibandingkan dengan umur tua. Petani yang berumur tua umumnya kemampuan untuk bekerja sudah berkurang dan lebih bersikap hati-hati dalam menerima sesuatu anjuran baru dalam kegiatan usahatninya. Hal ini disebabkan karena petani yang berumur tua telah matang dalam berpikir dan bertindak serta telah memiliki pengalaman yang cukup dalam berusaha tani, dengan demikian berakibat pada kurang dinamis dan cenderung tertutup terhadap hal-hal baru yang dianjurkan . Hal ini sejalan dengan pernyataan (Soeharjo \& Patong, 1984) yang mengemukakan bahwa faktor umur bagi petani dapat memengaruhi kemampuan fisik dalam bekerja. Pengelompokan umur didasarkan pada pendapat Soeharjo dan (Soeharjo \& Patong, 1984) bahwa usia produktif berkisar antara 15-54 tahun dan umur non produktif di atas 55 tahun.

Berdasarkan hasil penelitian yang ditemukan di Kelurahan NgkaringNgkaring menunjukkan bahwa umur petani responden bervariasi antara 33 tahun sampai dengan 71 tahun dengan rata-rata umur 44 tahun. Dari data umur tersebut bila dikelompokan berdasarkan umur produktif dan non produktif, maka dari keseluruhan petani responden yang mempunyai umur produktif (33-54 tahun) adalah berjumlah 43 orang atau $91,5 \%$ dan umur non produktif (55-71 tahun) berjumlah 4 orang atau $8,5 \%$. Perhatikan tabel berikut. 
Tabel 2. Keadaan Petani Responden Berdasarkan Pengelompokan umur Produktif dan Non Produktif di Kelurahan Ngkaring-Ngkari Tahun 2014

\begin{tabular}{ccc}
\hline $\begin{array}{c}\text { Umur } \\
\text { Responden } \\
\text { (tahun) }\end{array}$ & $\begin{array}{c}\text { Jumlah } \\
\text { (orang) }\end{array}$ & $\begin{array}{c}\text { Persentase } \\
(\mathbf{\%})\end{array}$ \\
\hline $33-54$ & 43 & 91,5 \\
$55-71$ & 4 & 8,5 \\
\hline Jumlah & $\mathbf{4 7}$ & $\mathbf{1 0 0 , 0 0}$ \\
\hline
\end{tabular}

Pada Tabel di atas, menunjukkan bahwa sebagian besar petani responden berada pada kelompok umur produktif sebanyak 43 orang $(91,5 \%)$ dan selebihnya 4 orang $(8,5 \%)$ berada pada umur non produktif . Kondisi ini menunjukan bahwa petani responden yang ada di Kelurahan NgkaringNgkaringmemiliki kemampuan bekerja lebih maksimal dan berpikir lebih maju sehingga diharapkan petani dapat menghasilkn produksi yang maksimal.

\section{b. Pendidikan}

Pendidikan pada umumnya dapat memengaruhi cara berpikir. Petani yang berpendidikan lebih tinggi cenderung bersifat dinamis dalam artian selalu berubah dalam penerapan teknologi disesuaikan dengan perkembangan zaman. Sebab petani yang memiliki pendidikan yang tinggi selalu berpikir logis akan seuatu yang dianggap baik pada masa yang lalu dan itu tidak selamanya berlaku tetapi mengalami perubahan sesuai dengan perkembangan kondisi lingkungan. menyesuaikan penggunadan selektif terhadap perubahan teknologi dengan pendidikan yang lebih tinggi diharapkan dapat merubah pola pikir petani kearah yang lebih rasional dan lebih tanggap terhadap informasi teknologi sehingga dapat meningkatkan produksi dan kualitas produksi yang dihasilkan serta dapat menyelesaikan setiap permasalahanpermasalahan yang dihadapi selama melakukan kegiatan usahtaninya. Hal ini sejalan dengan yang pendapat yang dikemukaakan oleh (Soeharjo \& Patong,
1984) bahwa kemampuan pengelolaan petani terhadap usahataninya sebagian besar ditentukan oleh tingkat pendidikan, baik yang bersifat formal maupun non formal. Makin tinggi pendidikan petani, makin mudah ia menerima, melaksanakan serta mengembangkan inovasi - inovasi baru dalam melakukan kegiatan usaha taninya yang pada akhirnya akan berdampak pada kegiatan usaha tani yang dilakukannya. Perhatikan tabel berikut.

Tabel 3. Tingkat Pendidikan Petani Responden di Kelurahan NgkaringNgkari Tahun 2014

\begin{tabular}{ccc}
\hline $\begin{array}{c}\text { Tingkat } \\
\text { Pendidikan }\end{array}$ & $\begin{array}{c}\text { Jumlah } \\
\text { (orang) }\end{array}$ & $\begin{array}{c}\text { Persentase } \\
\mathbf{( \% )}\end{array}$ \\
\hline Tamat SD & 15 & 31,9 \\
Tamat SMP & 17 & 36,2 \\
Tamat SMA & 13 & 27,7 \\
Sarjana (S1) & 2 & 4,2 \\
\hline Jumlah & $\mathbf{4 7}$ & $\mathbf{1 0 0 , 0 0}$ \\
\hline
\end{tabular}

Berdasarkan Tabel di atas, bahwa tingkat pendidikan petani responden terbanyak adalah tamatan Sekolah Menengah Pertama yang berjumlah 17 orang atau 36,2\%, Tamat Sekolah Dasar sebanyak 15 orang atau $31,9 \%$, tamat SMA sebanyak 13 orang atau $27,7 \%$ dan yang terkecil adalah tamatan Sarjana (S1) sebanyak 2 orang atau 2,5\%. Ini berarti secara keseluruhan responden telah mengenyam pendidikan formal dan bila dikaji lebih lanjut berdasarkan data menunjukan keinginan yang cukup besar dari petani yang ada di Kelurahan Ngkaring-Ngkari untuk melanjutkan pendidikan kejenjang yang lebih tinggi.

Hal ini dapat dilihat dari jumlah secara keseluruhan yang melanjutkan pendidikan ke tingkat SMP, SMA dan Sarjana berjumlah 32 orang atau $63 \%$. Hal ini tentunya akan memengaruhi pola pikir dari petani responden dalam hal pengambilan keputusan dari berbagai alternative keputusan yang harus diambil dalam upaya peningkatan dan pengembangan usaha tani padi sawah yang dilakukan oleh petani. Secara umum dengan tingkat pendidikan yang tinggi dapat dengan mudah menerima inovasi baru namun demikian dengan kondisi 
sekarang ini perlu dilakukan pendidikan lanjutan bagi semua umur masyarakat petani yang ada di pedesaan baik yang berumur muda maupun yang telah berumur tua sebab pendidikan yang mereka peoleh pada masa- masa yang lalu berbeda dengan kondisi sekarang ini,sudah banyak terjadi perubahanperubahan yang harus disesuaikan dengan kondisi alam sekarang ini, Oleh karena itu perlu adanya bantuan dari penyuluh pertanian lapangan untuk selalu mendampingi petani dalam melakukan kegiatan usahtaninya dan memberikan informasi tentang perkembangan teknologi -teknologi baru demi kemajuan usahataninya.

\section{c. Jumlah Tanggungan Keluarga}

Jumlah tanggungan keluarga merupakan salah satu faktor yang memengaruhi kegiatan ekonomi dan merupakan salah satu sumber dan aset dalam melakukan dan mengembangkan kegiatan usaha tani. Jumlah tanggungan keluarga yang dimaksud dalam penelitian ini adalah adalah jumlah semua anggota yang tinggal dalam satu keluarga tani dan merupakan bagian dari unit konsumsi rumah tangga. Jumlah tanggungan keluarga perlu mendapat perhatian. Hal ini disebabkan jumlah anggota keluarga merupakan sumberdaya yang dapat dikerahkan untuk membantu petani dalam melakukan kegiatan usaha taninya juga dengan banyaknya jumlah tanggungan keluarga petani akan memengaruhi aktifitas petani dalam menggerakan usaha taninya sebab dengan banyaknya tanggungan keluarga akan memberikan kelancaran kegitan petani pada usia produktif.

Di samping itu makin besar jumlah tanggungan keluarga maka makin besar pula jumlah kebutuhan yang harus dipenuhi oleh kepala keluarga, sehingga petani dituntut untuk lebih giat bekerja demi memenuhi kebutuhan hidup keluarganya. Jumlah tanngungan keluarga petani responden perhatikan tabel berikut.

Tabel 4. Jumlah Tanggungan Keluarga

Petani Responden di Kelurahan

Ngkaring-Ngkari Tahun 2014

\begin{tabular}{c|c|c}
\hline $\begin{array}{c}\text { Jumlah } \\
\text { Tanggungan } \\
\text { Keluarga } \\
\text { (orang) }\end{array}$ & $\begin{array}{c}\text { Jumlah } \\
\text { (orang) }\end{array}$ & $\begin{array}{c}\text { Persentase } \\
\mathbf{( \% )}\end{array}$ \\
\hline $2-4$ & 14 & 29,8 \\
$5-7$ & 33 & 70,2 \\
\hline Jumlah & $\mathbf{4 7}$ & $\mathbf{1 0 0 , 0 0}$ \\
\hline
\end{tabular}

Pada Tabel di atas, bahwa jumlah tanggungan keluarga petani responden di daerah penelitan berkisar 2-7 orang.dengan rata-rata 5 orang setiap petani responden. Jumlah petani responden yang memiliki tanggungan keluarga 2-4 orang berjumlah 14 orang atau 29,8\%, petani responden ynag memiliki jumlah tanggungan keluarga 5-7 orang berjumlah 33 orang atau $70,2 \%$. Hal ini menunjukan bahwa sebagian besar petani responden memiliki jumlah tanggungan keluarga yang cukup besar (5-7). Jumlah tanggungan keluarga tersebut dapat dijadikan sebagai tenaga keluarga yang setiap waktu dibutuhkan bersedia membantu.

Jumlah anggota keluarga tersebut dapat bernilai positif bila bersedia membantu petani sebagai kepala keluarga bekerja melakukan kegiatan usahataninya. Ini berarti bahwa anggota keluarga yang ada tersebut diharapkan dapat membantu petani sebagai kepala keluarga dalam mengelola usaha taninya sebagai sumber tenaga kerja. Namun keberhasilan usaha tani tidak hanya ditentukan oleh banyaknya anggota keluarga yang ada, akan tetapi juga ditentukan oleh keaktifan dan kontribusi yang dapat diberikan baik berupa saran yang maupun tenaga yang telah dicurahkan untuk kemajuan dan peningkatan produksi yang dihasilkan.

\section{d. Pengalaman Berusaha tani}

Petani dalam mengembangkan kegiatan usaha tani tentu tidak terlepas dari pengalam yang teah dilaluinya. 
Pengalaman berusaha tani merupakan salah satu faktor penting bagi petani responden dalam menentukan atau pengambilan keputusan dalam kegiatan usahtaninya. Pengalam merupakan proses pendidikan yang diperoleh dari luar bangku sekolah. Pengalaman berusaha tani akan selalu membawa perubahan bagi petani dalam mengelolah usaha taninya. Seorang petani dengan pengalaman yang banyak diharapkan dapat menentukan alternatif yang lebih baik sehubungan dengan usaha taninya. Pengalaman yang tinggi dapat memberikan suatu pelajaran yang bermanfaat sebab petani dapat belajar dari kesalahan yang pernah terjadi pada dirinya sehingga dapat dijadikan pedoman dalam merubah kebiasaankebiasaan yang buruk kearah yang lebih baik dimasa yang akan datang dalam berusaha tani.

Pengalaman berusaha tani dapat dikatakan cukup berpengalaman apabila menggeluti bidang pekerjaannya selama 5 -10 tahun. Sedangkan 10 tahun ke atas dikategorikan berpengalaman dan lebih lebih kecil dari 5 tahun dikategorikan kurang berpengalaman. Gambaran mengenai petani perhatikan tabel berikut.

Tabel 5. Pengalaman Responden Berusaha Tani

\begin{tabular}{ccc}
\hline $\begin{array}{c}\text { pengalaman } \\
\text { berusaha tani } \\
\text { (tahun) }\end{array}$ & $\begin{array}{c}\text { Jumlah } \\
\text { (orang) }\end{array}$ & $\begin{array}{c}\text { Persentase } \\
\mathbf{( \% )}\end{array}$ \\
\hline $5-10$ & 9 & 19 \\
$>10$ & 38 & 81 \\
\hline Jumlah & $\mathbf{4 7}$ & $\mathbf{1 0 0 , 0 0}$ \\
\hline
\end{tabular}

Pada Tabel di atas, bahwa keseluruhan petani telah melakukan kegiatan usaha tani diatas 5 tahun. Petani responden yang mempunyai pengalaman dari 5-10 tahun berjumlah 9 orang atau $19 \%$ dan petani dengan pengalaman diatas 10 tahun berjumlah 38 orang atau $81 \%$. Keadaan ini menggambarkan bahwa sebagian besar petani yang ada di Kelurahan Ngkaring-Ngkari dikategorikan berpengalaman dalam melakukan kegiatan usaha taninya. Dengan berpengalaman tersebut diharapkan petani mampu menghasilkan produksi padi sawah yang maksimal sebab petani dalam melakukan kegiatan usaha taninya dapat belajar dari pengalaman sebelumnya, dapat belajar dari kegagalan-kegagalan yang pernah dirasakanya sehingga dalam pengambilan keputusan akan lebih rasional dan penuh perhitungan yang pada akhirnya dengan keadaan yang berpengalaman tersebut sangat membantu petani dalam menganalisis dan menetukan setiap keputusan yang akan diambil.

\section{e. Luas Lahan Garapan}

Luas lahan garapan merupakan salah satu faktor produksi yang menentukan pengambilan keputusan seorang petani dalam melakukan kegiatan usaha tani. Luas lahan garapan juga menentukan jumlah produksi yang dihasilkan oleh petani dalam usaha tani yang dikelolanya. Makin luas lahan garapan yang dimiliki oleh petani maka makin bebas petani tersebut dalam menentukan dan mengelola lahan untuk diusahakan, dalam artian lebih leluasa menentukan jenis tanaman apa yang akan dikembangkan. Luas lahan yang dimiliki petani turut memengaruhi sikap dalam menentukan jenis usaha tani dan teknologi yang akan diterapkan dalam melakukan kegiatan usaha taninya.

Berdasarkan hasil penelitian diperoleh data luas lahan yang digarap petani responden bervariasi. Adapun luas lahan petani responden berkisar antara 0,5-2 Ha, dengan luas lahan rata-rata. 1,2 Ha. Perhatikan tabel berikut.

Tabel 6. Keadaan Luas lahan Garapan Petani responden di Desa NgkaringNgkaring Tahun 2014

\begin{tabular}{ccc}
\hline $\begin{array}{c}\text { Luas } \\
\text { Lahan(Ha) }\end{array}$ & $\begin{array}{c}\text { Jumlah } \\
\text { (Orang) }\end{array}$ & Persentase(\%) \\
\hline $0,5-1,25$ & 34 & 72,35 \\
$1,26-2$ & 13 & 27,65 \\
\hline Jumlah & $\mathbf{4 7}$ & $\mathbf{1 0 0 , 0 0}$ \\
\hline
\end{tabular}


Pada Tabel di atas, bahwa sebagian besar petani responden di Kelurahan Ngkaring - Ngkari yang berjumlah 34 orang atau $72,35 \%$ memiliki luas lahan 0,25-1,25 Ha dan 13 orang petani atau 27,65\% memiliki luas lahan 1,26-2. Berdasarkan data lahan tersebut bila diklasifikasikan dapat dikatakan keseluruhan petani responden memiliki luas lahan yang sedang. Hal ini tentu akan berpengaruh pada produksi yang dihasilkan, sebab lahan yang dikelolah petani merupakan salah satu faktor produksi yang penting dalam menentukan jumlah sarana produksi yang akan digunakan yang pada akhirnya akan berpengaruh pada kemampuan pencapaian yang dihasilkan.

\section{f. Produktivitas}

Produktivitas merupakan hasil per satuan luas, tenaga kerja, modal atau input lainnya. Orang luar cenderung mengukur produktivitas usaha tani menurut hasil total biomassa, hasil komponen-komponen tertentu, hasil ekonomis atau keuntungan, seringkali memandang perlu untuk memaksimalkan hasil per satuan lahan. Berdasarkan hasil penelitian di lokasi penelitian diperoleh data tentang produktifitas pada usaha tani padi sawah berkisar antara 1500-4.000 Kg/Ha. dengan produktiftas rata-rata 2.687 $\mathrm{Kg} / \mathrm{Ha}$. Untuk lebih jelasnya mengenai produktifitas pada usaha tani padi sawah petani responen di Kelurahan Ngkaring Ngkari pehatikan tabel berikut.

Tabel 7. Produktifitas Padi Sawah Petani Responden di di Kelurahan Ngkaring Ngkari Tahun 2014

\begin{tabular}{ccc}
\hline $\begin{array}{c}\text { Produktifitas } \\
\text { (Kg/Ha) }\end{array}$ & $\begin{array}{c}\text { Jumlah } \\
\text { (Orang) }\end{array}$ & Persentase(\%) \\
\hline $1.500-2.283$ & 18 & 38,29 \\
$2.284-3.067$ & 19 & 40,42 \\
$3.068-3.850$ & 10 & 21,29 \\
\hline Jumlah & $\mathbf{4 7}$ & $\mathbf{1 0 0 , 0 0}$ \\
\hline
\end{tabular}

Pada Tabel di atas, bahwa petani responden yang menghasilkan produktifitas antara $1.500-2.283 \mathrm{Kg} / \mathrm{Ha}$ berjumlah 18 orang atau $38,29 \%$, petani yang menghasilkan produktifitas 2.284$3.067 \mathrm{Kg} / \mathrm{Ha}$ berjumlah 19 orang atau $40,42 \%$ dan petani yang menghasilkan produktifitas $\quad 3.068-3.850 \quad \mathrm{Kg} / \mathrm{Ha}$ sebanyak 10 orang atau 21,29\%. Kenyataan ini menggambarkan bahwa produktifitas yang dihasilkan oleh petani responden di desa Ngkari-Ngkari berbeda-beda. Perbedaan hasil produktifitas padi sawah yang dihasilkan tersebut disebabkan Hal ini disebabkan oleh perbedaan penggunaan jumlah bibit, penggunaan pupuk yang tidak seimbang, kurangnya penggunaan obat-obatan ataupun penggunaan obat-obatan yang berlebihan, kondisi kandungan bahan organik setiap lahan petani responden yang berbeda-beda,penggunaan tenaga kerja yang tidak maksimal pada saat dibutuhkann terutama pada saat pemberantasan hama dan penyakit tanaman.

\subsection{Pengaruh Faktor-Faktor Produksi Terhadap Produktifitas pada Usaha tani Padi Sawah \\ Penelitian yang dilakukan di} Kelurahan Ngkari-Ngkari tentang pengaruh faktor-faktor produksi terhadap produktifitas usaha tani padi sawah yang dianalisis dengan menggunakan dengan menggunakan Analisis Regresi Linear Berganda.

\subsection{Analisis Pengaruh Faktor - Faktor Produksi Secara Simultan Terhadap Produktiftas Usaha tani padi sawah di Kelurahan Ngkari-Ngkari}

Ho = Tidak ada pengaruh luas lahan, bibit, tenaga kerja, bibit, dan pestisida secara bersama-sama terhadap produktifitas usaha tani padi sawah.

$\mathrm{H} 1=$ Ada pengaruh luas lahan, bibit,tenaga kerja, pupuk dan 
pestisida secara simultas terhadap produktiftas usaha tani padi sawah

Berdasarkan hasil perhitungan regresi berganda dengan menggunakan bantuan program SPSS version 19.00, menunjukan bahwa faktor-faktor produksi variabel bebas yang meliputi luas lahan, bibit, tenaga kerja, pupuk dan obat-obatan secara bersama- sama dan signifikan memengaruhi variabel terikat (produktifitas). Hal ini dapat dilihat pada hasil analisis yang dilakukan diperoleh nilai signifikansi sebesar 0,000. Nilai probabilitas tersebut tersebut lebih kecil bila dibandingkan dengan nilai signifikansi atau taraf kepercayaan $=(\mathrm{Sig}$ $<0,05)$, dengan demikian dapat dikatakan bahwa Ho ditolak dan Ha yang diajukan diterima yang berarti bahwa luas lahan, bibit,tenaga kerja, pupuk dan obat-obatan secara bersama- sama dan signifikan memengaruhi variable terikat (produktifitas) usaha tani padi sawah. Umumnya setiap petani di dalam berusaha tani berbeda beda daalam melakukan kegiatan yang berhubungan dengan produksi khususnya padi sawah.

Tabel 8. Hasil Analisis Regresi Linear Berganda (ANOVA)

\begin{tabular}{|c|c|c|c|}
\hline Model & $\begin{array}{l}\text { Sum of } \\
\text { Squares }\end{array}$ & df & $\begin{array}{c}\text { Mean } \\
\text { Square }\end{array}$ \\
\hline Regression & 21316557.096 & 5 & 4263311.419 \\
\hline Residual & 6751006.606 & 41 & 164658.698 \\
\hline Total & 28067563.702 & 46 & \\
\hline
\end{tabular}

Berdasarkan hasil analisis regresi Linear Berganda, diperoleh nilai koefisien determinasi R Square sebesar 0,759. Nilai ini menunjukan besarnya persentase pengaruh variable bebas yang meliputi luas lahan, bibit,tenaga kerja, pupuk dan pestisida secara simultan atau bersamasama terhadap variabel terikat (Produktifitas padi sawah) sebesar 75,9\% dan selebihnya $24,1 \quad(100 \%-\quad 75,9 \%)$ dipengaruhi oleh faktor-faktor lain diluar faktor-faktor penelitian. Untuk lebih jelasnya hasil analisisnya perhatikan tabel berikut.

Berdasarkan hasil Analisis Regresi Linear berganda yang dilakukan maka diperoleh nilai sig untuk mengetahui pengaruh factor-faktor produksi petani terhadap produktiftas padi sawah di Kelurahan Ngkari-Ngkari. Untuk lebih jelasnya dapat dilihat pada tabel berikut:

\begin{tabular}{|c|c|c|c|c|c|c|}
\hline & \multirow{3}{*}{ Model } & \multicolumn{2}{|c|}{ Unstandard } & \multirow{2}{*}{$\begin{array}{c}\text { Standardized } \\
\text { Coefficients }\end{array}$} & \multirow{3}{*}{$t$} & \multirow{3}{*}{ Sig } \\
\hline & & Coef & ents & & & \\
\hline & & B & Std. Error & Beta & & \\
\hline \multirow[t]{6}{*}{1} & (Constant) & 1370.989 & 277.224 & & 4.945 & .000 \\
\hline & Lahan & -802.119 & 290.666 & -.493 & $\begin{array}{c}- \\
2.760\end{array}$ & .009 \\
\hline & Bibit & 11.107 & 6.399 & .299 & 1.736 & .040 \\
\hline & $\begin{array}{l}\text { Tenaga } \\
\text { kerja }\end{array}$ & -.101 & 4.102 & -.002 & -.025 & .981 \\
\hline & Pupuk & 1.010 & .388 & .311 & 2.606 & .013 \\
\hline & Pestisida & 519.958 & 136.744 & .769 & 3.802 & .000 \\
\hline
\end{tabular}

\subsection{Analisis Pengaruh Luas Lahan Terhadap Produktifitas Pada Usaha tani Padi sawah di Kelurahan Ngkari-Ngkari}

Ho : Tidak ada pengaruh yang signifikan antara luas lahan secara parsial terhadap produktifitas usaha tani padi sawah

H1 : Ada pengaruh yang signifikan antara luas lahan secara parsial terhadap produktifitas terhadap F Sig. padi sawah.

usaha tani

00Berdasarkan hasil analisis yang dilakukan diperoleh nilai Signifikansi sedpear 0,009. Nilai probabilitas ini lebih kecil bila dibandingkan dengan nilai taraf kepercayaan sig $=0,05$. Dengan demikian maka Ho ditolak dan H1 diterima. Dengan demikian dapat dikatakan bahwa luas lahan berpengaruh signifikan terhadap produktifitas usaha tani padi sawah. Keadaan ini menunjukan bahwa petani yang memiliki lahan yang luas dapat menghasilkan produksi yang lebih tinggi dibandingkan dengan petani yang memiliki luas lahan yang kecil kemampuan produksi yang sama, dalam artian bahwa lahan yang luas bila tidak Hal ini menujukan bahwa semakin besar 
luas lahan garapan yang dimiliki dan dikelolah oleh petani responden maka semakin tinggi produktifitas yang dihasilkan pada usaha tani pada kubis tersebut, sebab luas lahan garapan akan menentukan intensitas kegiatan usaha taninya dan semakin luas lahan yang dikuasai oleh petani responden makin leluasa petani merencanakan penggunaan tanahnya dan semakin bersemangat untuk mengontrol kegiatan usaha taninya. Hal ini sejalan dengan pendapat (Mosher, 1984) bahwa penguasaan petani terhadap sumber daya lahan yang dimilki akan menentukan produktiifitas usaha tani yang dihasilkannya dan pada gilirannya akan memengaruhi tingkat pendapatan.

Lahan yang dimiliki oleh petani merupakan salah satu faktor produksi yang penting menentukan besar kecilnya produksi yang dihasilkan sebab semakin luas lahan yang digarap maka akan semakin besar pula hasil produksi yang dihasilkan dalam kondisi faktor-faktor yang lain mendukung baik dalam penggunaan pupuk,obat-obatan maupun tenaga kerja

\subsection{Pengaruh Bibit Terhadap Produktifitas pada Usaha Tani Padi Sawah di Kelurahan Ngkari-Ngkari}

Ho : Tidak ada pengaruh yang signifikan antara penggunaan bibit secara parsial terhadap produktifitas usaha tani padi sawah

H1 : Ada pengaruh yang signifikan antara penggunaan bibit secara parsial terhadap produktifitas usaha tani padi sawah

Berdasarkan hasil analisis yang dilakukan diperoleh nilai signifikansi sebesar $(\mathrm{Sig}=0,030)$.Nilai probabilitas lebih kecil bila dibandingkan dengan taraf kepercayaan ( siginifikan= 0,040). Dengan demikian dikatakan Ho ditolak dan Ha diterima, yang berarti bahwa penggunaan bibit berpengaruh signifikan terhadap produktifitas padi sawah, Hal ini menunjukan bahwa penggunaan bibit dapat memengaruhi produktififtas padi sawah dilokasi penelitian. Petani dalam melakukan kegiatan usahatai padi sawah terutama penggunaan bibit disesuaikan dengan luas lahan yang digarap, semakin luas tanah yang akan ditanami tanaman padi sawah maka semakin banyak bibit yang akan digunakan dan akan berdampak pada hasil produksi yang dihasilkan yang berdasarkan hasil penelitian menunjukan semakin meningkat pula hasil produktiftasnya.

Namun hal ini perlu didukung dengan penggunaan sarana produksi yang dianjurkan dan sesuai dengan dosis, pandangan tersebut sejalan dengan (Soekartawi, 1990) yang menyatakan bahwa terdapat faktor yang memengaruhi produksi yaitu faktor biologi, seperti lahan pertanian dengan macam dan tingkat kesuburannya, bibit, pupuk, obat-obatan dan sebagainya. Dari produksi yang dihasilkan tersebut akan dapat diketahui kemampuan tiap hektar yang dihasilkan atau dengan kata lain dapat diketahui tingkat produktiftasnya.

\subsection{Pengaruh Tenaga Kerja Terhadap Produktifitas Pada Usaha tani Padi sawah di Kelurahan Ngkaring-Ngkari}

Ho : Tidak ada pengaruh yang signifikan antara tenaga kerja secara parsial terhadap produktifitas usaha tani padi sawah.

H1 : Ada pengaruh yang signifikan antara tenaga kerja secara parsial terhadap produktifitas usaha tani padi sawah.

Berdasarkan hasil analisis regresi Linear Berganda yang dilakukan diperoleh nilai signifikansi 0,981 probabilitas tersebut lebih besar bila dibandingkan dengan taraf kepercayaan $($ sign $=0,05)$. Hal ini berarti probabilitas $(0,981)$ lebih besar bila dibandingkan 
dengan taraf siginifikan $=0,05$. Dengan demikian Ho diterima dan $\mathrm{H} 1$ ditolak hal ini dapat dikatakan bahwa produktifitas padi sawah tidak dipengaruhi secara signifikan oleh tenaga kerja petani di Kelurahan Ngkari- Ngkari . Keadaan ini khusus di lokasi penelitian penggunaan jumlah tenaga kerja yang banyak dan yang menggunakan tenaga kerja kurang memiliki peluang yang sama dalam menghasilkan produksi. Sebab penggunaan tenaga kerja dalam jumlah yang banyak akan tetapi tidak bekerja secara maksimal dengan jam kerja yang tidak maksimal tentu akan menghasilkan produktiftas yang tidak sesuai dengan harapan.dalam jumlah memiliki potensi yang sama jumlah tanggungan keluarga yang dimiliki oleh petani responden walaupun berdasarkan hasil penelitian diperoleh rata-rata 4 orang tiap petani, namun jumlah tanggungan keluarga tersebut tentunya dapat bernilai positif dan negatif dalam arti bisa memberikan kontribusi yang cukup besar bagi petani bila anggota keluarga tersebut membantu petani secara maksimal dalam melakukan kegiatan usaha taninya namun bisa juga merupakan beban bagi petani bila anggota keluarga tersebut tidak ikut terlibat dalam kegiatan usaha tani sehingga akan berdampak pada hasil produktifitas yang dicapai menjadi tidak maksimal.

\subsection{Pengaruh Penggunaan Pupuk Terhadap Produktifitas Usaha tani Padi Sawah}

Ho: Tidak ada pengaruh yang signifikan antara penggunaan pupuk secara parsial terhadap produktifitas usaha tani padi sawah.

H1 : Ada pengaruh yang signifikan antara pupuk secara parsial terhadap produktifitas usaha tani padi sawah

Berdasarkan hasil analisis yang dilakukan diperoleh nilai signifikansi sebesar $($ Sig= 0,013), nilai probabilitas ini lebih kecil bila dibandingkan dengan taraf kepercayaan (siginifikan $=0,05$ ), Dengan demikian Ho ditolak dan H1 diterima, yang berarti penggunaan pupuk berpengaruh signifikan terhadap produktivitas usaha tani padi sawah. Keadaan ini menujukan bahwa penggunaan pupuk oleh petani responden dilokasi penelitian memberikan pengaruh terhadap produksi padi sawah yang dihasilkan. Petani yang menggunakan pupuk yang sesuai dengan anjuran dalam artian sesuai dengan dosisinya tentunya akan memberikan hasil yang maksimal.

Hasil penelitian ini seseuai dengan hasil wawancara dengan salah satu responden yang menyatakan bahwa dalam melakukan kegiatan usaha tani padi sawah penggunaan pupuk yang seimbang yang sesuai anjuran sangat berpengaruh terhadap hasil produksi tiap hektarnya, lebih lanjut menyatakan bahwa dengan penggunaan pupuk akan berbeda hasilnya dengan petani yang lain yang tidak menggunkaan pupuk sebab tanah yang telah lama digunakan untuk ditanami padi kandungan bahan organiknya akan semakin berkurang sehingga untuk menghasilkan produksi yang maksimal harus dengan penggunaan pupuk yang seimbang.

Pandangan tersebut didukung oleh (Ismunadji, 1983) besar kecilnya produksi yang diperoleh ditentukan oleh kemampuan petani dalam menerapkan teknologi yang ada dan yang menyebabkan perbedaan-perbedaan produksi padi sawah yang dicapai oleh setiap petani yaitu teknologi tidak sepenuhnya diserap oleh petani.

\subsection{Analisis Pengaruh Pestisida Terhadap Produktifitas pada Usaha Tani Padi Sawah di Kelurahan Ngkaring-Ngkari}

Ho : Tidak ada pengaruh yang signifikan antara pestisida secara parsial terhadap produktifitas usaha tani padi sawah. 
H1 : Ada pengaruh yang signifikan antara pestisida secara parsial terhadap produktifitas usaha tani padi

Berdasarkan hasil analisis uji t yang dilakukan diperoleh nilai $\mathrm{t}$ sebesar 3,802 dengan signifikansi sebesar( $\operatorname{sig}=0,00)$, Hal ini berarti Probabilitas $(0.000$ lebih kecil bila dibandingkan taraf kepercayaan $=0,05$. Dengan demikian Ho ditolak dan H1 diterima dapat dikatakan bahwa pestisida berpengaruh signifikan terhadap produktifitas usahtani padi sawah.Hal ini menunjukan bahwa petani responden yang menggunakan pestisida pada tanaman yang terserang hama penyakit yang sesuai dengan takarannya akan memberikan hasil produktiftas yag maksimal sesuai dengan hasil penelitian. Diketahui bahwa petani responden yang ada di Kelurahan Ngkaring-Ngkari merupakan petani yang sudah lama dan paham akan manfaat penggunaan pestisida pada tanaman hanya saja yang menbedakan antara petani yang satu dengan petani yang lain adalah jumlah pestisida dan jenis pestisida yang akan digunakan dan tingkat keinginan masyarakat untuk serius menggunakan dengan dosis yang tepat.

\subsection{Variabel Dominan}

Berdasarkan tabel Coefisient dan penjelasan di atas dapat dikatakan bahwa dari kelima variabel bebas yaitu variable luas lahan (X1), bibit (X2) tenaga kerja (X3), pupuk (X4) dan pestisida (X5) maka variable yang dominan memberikan pengaruh terhadap produtivitas usaha tani padi sawah adalah variabel obat-obatan (Pestisida) (X5) sehingga dapat dituliskan persamaan regresinya sebagai berikut.

$Y=1370.989-802,119$ X1 + 11,107 X2 -101 X3 + 1.010 X4 + $519,958 \times 5+e$

\section{KESIMPULAN}

Simpulan penelitian ini adalah Berdasarkan hasil analisis regresi linear berganda menunjukan bahwa variabel luas lahan, bibit, tenaga kerja, pupuk, dan pestisida secara bersama- sama berpengaruh signifikan terhadap produktivitas usahatani padi sawah. pengaruh yang diberikan sebesar 75,9\% dan selebihnya $24,1 \%$ dipengaruhi oleh variabel yang lain diluar variabel penelitian; Hasil analisis secara parsial diperoleh nilai Sig sebesar 0,009. Nilai tersebut menunjukan bahwa Luas lahan berpengaruh signifikan terhadap produktifitas usahatani padi sawah. Semakin luas lahan yang dikelola oleh petani maka semakin besar produksi dan akan terimplementasi pada produktivitas yang dihasilkan juga mengalami kenaikan; Hasil analisis secara parsial diperoleh nilai sig $=0,04$. Nilai tersebut menunjukan bahwa penggunaan bibit berpengaruh signifikan terhadap produktifitas usahatani padi sawah; Hasil analisis secara parsial diperoleh nilai sig $=$ 0,981 . Nilai tersebut menunjukan bahwa tenaga kerja tidak berpengaruh signifikan terhadap produktivitas usaha tani padi sawah. Sebab tenaga kerja yang dicurahkan tidak bekerja secara maksimal; Hasil analisis secara parsial diperoleh nilai sig $=0,013$. Nilai tersebut menunjukan bahwa pupuk berpengaruh signifikan terhadap terhadap produktivitas usaha tani padi sawah; dan Hasil analisis secara parsial diperoleh nilai sig $=0,000$. Nilai tersebut menunjukan bahwa pestisida berpengaruh signifikan terhadap produktivitas usaha tani padi sawah.

\section{DAFTAR PUSTAKA}

Arikunto, S. (2002). Metodologi Penelitian Suatu Pendekatan Proposal. Jakarta: PT. Rineka Cipta.

Biro Pusat Statistik. (1993). Hasil Sensus Pertanian.

BPS, B. (2011). Baubau Dalam Angka. BPS, B. (2013). Bau-Bau Dalam Angka. Gujarati, D. (2003). Ekonometri Dasar. Terjemahan: Sumarno Zai. Jakarta: Erlangga.

Ismunadji. (1983). Peranan Penelitian Padi 
Sawah Dalam Pembangunan Pertanian.

Universitas Hasanuddin.

Mosher, A. T. (1984). Menggerakan dan

Membangun Pertanian. CV Yasaguna.

Soeharjo, \& Patong, D. (1984). Sendi -

Sendi Pokok Ilmu Usaha Tani.

Universitas Hasanuddin.

Soekartawi. (1990). Analisis Usaha tani.

Universitas Indonesia Press.

Sufridson, et al. (1989). Efisiensi Ekonomi

Pada Usaha Tani Padi di Kalimantan

Tengah, Berskala Penelitan Pasca

Sarjana Universitas Gadja Mada

(BPPSUGM). Universitas Gadja

Mada. 